УДК 378.016:796/799(07)

DOI: 10.37026/2520-6427-2020-102-2-180-183

\author{
Михайло ГАЛАТЮК, \\ кандидат педагогічних наук, \\ доиент кафедри педагогіки, \\ освітнього менеджменту та соиіальної роботи \\ Рівненського державного гуманітарного університету
}

\title{
СУЧАСНИЙ СТУДЕНТСЬКИЙ СПОРТ ЯК МОДУС РОЗВИТКУ СПОРТИВНОЇ КУЛЬТУРИ МАЙБУТНІХ ФАХІВЦІВ ФІЗИЧНОГО ВИХОВАННЯ
}

У статті окреслено проблеми, шо стосуються фізичної активності студентів. Здійснено аналіз поняття "спорт», зокрема запропоновано визначення даного феномену в контексті сталого розвитку суспільства. Схарактеризовано сучасний студентський спорт як спосіб розвитку спортивної культури майбутніх фахівиів фізичного виховання.

Ключові слова: спортивна культура, фізичне виховання, майбутній фахівеиьь, розвиток, студентський спорт, змагальна діяльність.

В статье обозначены проблемы, касаюшиеся физической активности студентов. Осуществлен анализ понятия "спорт», в частности предложено определение даного феномена в контексте устойчивого развития общества. Охарактеризован современный студенческий спорт как способ развития спортивной культуры будущих специалистов физического воспитания.

Ключевые слова: спортивная культура, физическое воспитание, будущий спеииалист, развитие, студенческий спорт, соревновательная деятельность.

The article outlines problems that are relevant physical activity of students. The attention is on the problem of development of sports culture of future specialists in physical education. The author analyzed the concept of «sport». Is installed, that modern sports - important component of the culture of society. Modern sport is one of the most common activities in the world.

The author has considered modern sport in context needs of sustainable development of society. The suggested of definition of modern sport as a tool for sustainable development of society. On the basis of the analysis of scientific literature, the highlighted varieties of modern sport as an activity. The defined of content of student sports. Found out the essence of basic sports and amateur. The disclosed student sports as a way of developing sports culture.

The mission of student sports the involvement of future specialists to systematic sports activity. This mission is realized through educational-training and competitive activities of future specialists in physical education. Student sport promotes harmonious development of personality. Student sport is aimed at achieving high sports results in the chosen sport.

Modern student sport is characterized by many forms of physical activity. An important role in the development of the student sports movement belongs to the centers of student sports, sports clubs and sections. In centers of student sports are laid the foundations of the higher sports skill of students. These centers are the main institutions development of sports culture of future specialists in physical education.

Student sport is not only a way of developing sports culture, but also a means of reforming physical education in higher education institutions.

Key words: sports culture, physical education, future specialist, development, student sports, competitive activities.

Постановка проблеми. Обов'язком сучасних педагогічних закладів вищої освіти є підготовка не лише компетентного фахівця фізичного виховання, а й усебічно розвиненої особистості, захисника Вітчизни, здатного успішно долати різноманітні життєві проблеми та виклики. У зв'язку з цим сучасний фахівець фізичного виховання повинен постати як вольова, гармонійно розвинена особистість, спроможна виправдати інвестиційний кредит довіри, вкладений у неї державою. Підготовка майбутнього фахівця, наділеного означеними вище якостями, стане реальністю за умов ревалоризації значущості студентського спортивного руху як на рівні закладів вищої освіти, так і держави в цілому.

Сьогодні лишається невирішеною проблема виявлення потенціалу обдарованих студентів, які спроможні не лише бути компетентними фахівцями фізичного виховання, а й досягати неабияких успіхів у спорті та тренерській діяльності. Важливе місце у вирішенні означеної проблеми, на нашу думку, 
належить студентському спорту, його орієнтованості на розвиток спортивної культури майбутніх фахівців фізичного виховання.

Аналіз наукових досліджень і публікацій довів, що актуальною проблемою сьогодення $є$ вдосконалення структури та змісту студентського спорту, характеристика його науково-методичного забезпечення, вдосконалення нормативно-правового регулювання спортивної діяльності (М. Мельник, М. Пітин, Ю. Мічуда, М. Дутчак, Є. Імас та ін.) [8].

Деякі аспекти проблеми сучасного студентського спорту висвітлено в наукових розвідках С. Степанюк, О. Вацеби, А. Войнаровського та ін., зокрема здійснено історичний аналіз розвитку студентського спорту в закладах вищої освіти, розкрито передумови становлення, основні періоди формування й розвитку студентського спортивного руху в Україні, окреслено значний ціннісний і культурний потенціал студентського спорту.

Праці вчених свідчать про неабиякий інтерес до студентського спорту в контексті формування людиновимірності та цілісності особистості. Передусім закцентовується увага на спорті як способі становлення особистості, що пов'язано з розвитком перспективного наукового напряму - філософії спорту. У низці досліджень $[1 ; 5]$ розглядаються філософські аспекти спорту, розкриваються взаємозв'язки феноменів творчості, гри і спорту як когнітивних матриць цілісності особистості, доводиться, що спорт є вільним виявом свідомої людини, універсальним способом самостворення та самовдосконалення організму.

Аналіз перспективних наукових досліджень, які стосуються якісних змін у розвитку спортивного руху студентської молоді, засвідчує про відсутність системних підходів до вирішення проблем низької фізичної активності студентів. Додаткової уваги науковців вимагає проблема обгрунтування і розробки цілісної системи розвитку студентського спорту. Ми вважаємо, що вона повинна враховувати засади національно-патріотичного виховання молодого покоління, а також риси української ментальності.

Результати аналізу теорії і практики фізичного виховання та спортивної підготовки молоді свідчать про актуальність розвитку спортивної культури і пошуку шляхів підсилення мотивації студентів до занять спортом. Вимогою часу в цьому контексті $\epsilon$ розгляд дидактичних умов розвитку спортивної культури майбутніх фахівців фізичного виховання з урахуванням сучасних можливостей студентського спорту. Таким чином, необхідно обгрунтувати і розробити систему принципів, форм і засобів успішного розвитку спортивної культури майбутніх фахівців фізичного виховання на основі залучення їх до студентського спортивного руху.

Бесіди з викладачами та спілкування з майбутніми фахівцями фізичного виховання засвідчують відсутність єдиної думки щодо змістового та дидактичного наповнення поняття спортивної культури в контексті фахової підготовки студентів. Саме це є однією 3 причин стихійності в розвитку спортивної культури. Стихійність породжується також наявністю проблем матеріально-технічного забезпечення студентського спорту, низьким рівнем мотивації до занять спортом, неготовністю поєднувати навчання із тренувальною і змагальною діяльністю. Як наслідок - відсутність орієнтації майбутніх фахівців фізичного виховання на досягнення конкретних спортивних результатів.
Отже, актуальним є обгрунтування і розвиток дидактики студентського спорту як наукового напряму, а одним із важливих завдань у цьому контексті - розкриття його соціокультурного феномену.

Мета статті - 3'ясувати сутність студентського спорту; схарактеризувати сучасний студентський спорт як спосіб розвитку спортивної культури майбутніх фахівців фізичного виховання.

Виклад основного матеріалу. Для багатьох студентів спорт - це найдоступніший, надійний і безпечний вид діяльності, який позитивно впливає на психоемоційний і фізичний стан здоров'я, допомагає подолати стресові ситуації, викликані низкою змін у студентському житті, як-от: екзаменаційна сесія, підробіток, стосунки з ровесниками тощо. Студентський спорт $є$ частиною життя молодих людей і культури їхнього дозвілля. Завдяки студентському спорту закладаються найкращі якості майбутнього фахівця, відбувається становлення студента як високоморальної, духовно-тілесної особистості [1].

Щоб розкрити культурний потенціал студентського спорту, його слід розглядати крізь призму мотиваційної сфери майбутнього фахівця, тобто сфери його потреб і можливостей. У зв'язку з цим потреба вийти за межі можливостей і саморух до них є істотним процесом людиновимірності [5, с. 175], адже, як зазначає В. Білогур, саме в спорті закладені можливості реалізації людиновимірної функції культури [1].

Досліджуючи проблеми методології спорту, М. Вiзітей розглядає поняття «спорт» як особливий вид діяльності людини. Порівнюючи сутності феноменів «фізична культура» і «спорт», науковець стверджує, що саме спорт доцільно визначити як вид офіційної змагальної діяльності, в якій змагальний момент неабияк чітко виражений і самодостатній. Отже, спорт можна вважати «суто змагальною діяльністю», в якій відтворюється (продукується) змагальність [2, с. 49].

Під час занять спортом особистість долає певні життєві перепони, виходить за їх межі, підвищує власний рівень спортивної культури, розширює свої можливості та потенціал. Завдяки цьому сучасний спорт можна назвати «царством рафінованої свободи», модусом становлення особистості, адже саме чеpeз гру людина «пропускає» все своє життя [1, с. 29].

Сучасний спорт є складним і малодослідженим соціокультурним феноменом. Він характеризується неабиякою різноманітністю: масовий спорт, або «спорт для всіх»; спорт вищих досягнень (професійний); любительський та аматорський спорт; студентський та шкільний спорт; спорт для інвалідів - інваспорт тощо.

У науково-методичній літературі 3 підготовки спортсменів [6] наявні різні трактування спорту. 3окрема, проведені нами розвідки, що стосуються обгрунтування концепції «спорт заради розвитку» [3], аналізу соціології та філософії спорту $[1 ; 2 ; 5]$, дали змогу встановити зміст поняття «спорт» у наративі розвитку спортивної культури особистості.

Зважаючи на викладене вище, зауважимо, що в контексті нашого дослідження спорт є одним зі способів самореалізації людини, тобто під цим поняттям розумітимемо всі форми фізичної активності людини, що сприяють їі фізичному й психічному здоров'ю, благополуччю, а також покращують можливість соціальної взаємодії між людьми. До форм фізичної активності відносять: ігри (предметні, змагальні та рольові); організацію дозвілля; 
змагальні види спорту; історично притаманні певним країнам національні види спорту та ігри та ін. До найбільш істотних ознак спорту відносять змагальну діяльність, суперництво, змагальність, досягнення спортивного результату. Таким чином, спорт - це змагальна діяльність, яка відбувається 3 дотриманням принципу рівності, тобто однакових шансів на успіх для всіх учасників змагання.

Сучасний спорт, за твердженням Організації Об’єднаних Націй, а також ЮНІСЕФ, світового лідеpa із захисту прав підростаючого покоління, є засобом забезпечення потреб сталого розвитку суспільства та способом встановлення взаєморозуміння між людьми, який чинить неабиякий вплив на підвищення продуктивності взаємодії між країнами в трьох важливих напрямах сталого розвитку: економічному, соціальному й екологічному. У зв'язку з цим перед країнами, які займають сьогодні у світі провідні позиції, постає надскладне завдання - досягти балансу цих трьох напрямів. Тобто сучасний спорт спрямований саме на подолання неузгодженостей у вирішенні непростих проблем, які стосуються побудови моделі подальшого розвитку цивілізації. Ця модель грунтується на засадах концепції сталого розвитку суспільства.

Неабияка заслуга спорту полягає і в його здатності виконувати об'єднуючу функцію в соціальних стосунках. Спортивні змагання, встановлені спортивні контакти зазвичай сприяють розвитку переконань, поглядів та еталонів поведінки особистості. Позитивні якості людини нівелюють відчуженість, сприяють взаємоповазі, допомагають долати міжкультурні бар'єри та встановлювати стійкі соціальні взаємозв'язки. По-іншому - спорт сприяє особистісній соціальній інтеграції, що є наслідком особливостей спортивних змагань - суперництва між сторонамиучасниками в штучно створених умовах [3].

Аналіз нормативних документів [4; 9] дає змогу визначити правові, організаційні, соціальні та економічні засади розвитку студентського спорту. Зокрема, варто зауважити, що студентський спорт - це спортивні заняття за державними програмами, які проводяться в закладах вищої та спеціалізованої освіти (школи-інтернати, професійні коледжі спортивного профілю тощо) різних форм власності; участь у спортивних змаганнях; заняття в спортивних секціях і командах 3 ігрових видів спорту, які перебувають під егідою громадських організацій спортивного спрямування, наприклад, спортивних клубів. Щодо ЗВО, то студентський спорт тут передусім спрямований на освоєння тих видів спорту, в яких рухові вміння і навички, набутий досвід спортивної підготовки не лише розвивають спортивну культуру, а й повною мірою відповідають професійній діяльності майбутнього фахівця [6].

Ми погоджуємося 3 думкою низки дослідників, що спорт як вид діяльності поділяється на масовий i спорт вищих досягнень. Студентський спорт належить до масового спорту, який у науково-методичній літературі представлений як базовий спорт і спорт самодіяльнісний. Особливістю базового студентського спорту є наявність спеціально розробленої програми спортивної підготовки, на основі якої відбуваються систематичні заняття під керівництвом викладача-тренера. Відповідно до цієї програми здійснюється навчально-тренувальний процес, що передбачає посилену теоретичну, фізичну, психологічну і техніко-тактичну підготовку студента з обра- ного виду спорту. Наскрізним завданням реалізації програми спортивної підготовки є збереження і покращення здоров'я сучасних студентів.

Самодіяльнісний студентський спорт - найбільш поширена форма активного відпочинку студентської молоді. Серед основних ознак самодіяльнісного спорту - відсутність цілі, що передбачає досягнення вагомих результатів 3 обраного виду спорту, його розважальна мета, стихійний розвиток спортивної культури, відсутність програми тренувань і постійного наставника, який здійснює управління навчально-тренувальним процесом [6]. У сучасних закладах вищої освіти самодіяльнісний спорт представлений різноманітними формами спортивної самоорганізації студентів.

Сучасний студентський спорт виконує важливу місію, що полягає в залученні майбутніх фахівців до систематичної спортивної активності. При цьому метою спортивної активності $\epsilon$ гармонійний розвиток особистості й досягнення високих спортивних результатів з обраного студентом виду спорту, визнаного в Україні та за кордоном. Сьогодні в більшості закладів вищої освіти, як правило, наявні центри студентського спорту як основні установи фізичного виховання молоді, де забезпечуються сприятливі умови для поєднання навчання та підготовки студентів до участі в спортивних змаганнях різних рівнів.

У центрах студентського спорту закладаються основи вищої спортивної майстерності, студенти-спортсмени у складі збірних команд України збагачуються цінним досвідом. Так, участь у спортивних змаганнях різного рівня, присутність уболівальників позитивно впливає на розвиток спортивної культури студентів, а відвідування спортивних семінарів і майстер-класів за участю професійних спортсменів неабияк розвиває спортивну культуру майбутніх фахівців, формує їхній спортивний стиль [4; 7]. Зважаючи на це, студентський спорт $є$ не лише доповненням професійної підготовки майбутніх фахівців фізичного виховання, а й допомагає під іншим кутом зору поглянути як на власне здоров'я, так і майбутні життєві перспективи.

Розвиток студентського спортивного руху, виховання талановитої молоді в студентських спортивних клубах і секціях - один із важливих критеріїв оцінки культурно-дозвіллєвої і спортивної діяльності закладів вищої освіти. Студентський спорт $є$ способом формування позитивного іміджу ЗВО, завдяки чому останній отримує можливість ідентифікуватися завдяки участі кращих студентів-спортсменів у літніх і зимових Універсіадах, Світових університетських чемпіонатах.

Таким чином, від перспектив розвитку напрямів студентського спорту, його структури та змісту діяльності залежить якість професійного становлення сучасного фахівця фізичного виховання. У процесі підготовки студентських команд, їх участі в спортивних змаганнях створюються максимально комфортні умови, що сприяють розвитку спортивної культури майбутніх фахівців, а спільні спортивні тренування і командна робота дає змогу для реалізації їхнього особистісного потенціалу. На нашу думку, важливу на сьогодні проблему розвитку спортивної культури студентів можна вирішити завдяки створенню спортивних клубів і спортивних секцій із різних видів спорту, облаштуванню спеціальних спортивних майданчиків для тренувань, а ще - залученню кваліфікованих спортивних інструкторів і викладачів, які зможуть поділитися 3 майбутніми фахівцями своїм досвідом та вміннями. 
Висновки. Сучасному студентському спорту притаманна система інструментів, що здатні подолати кризу фізичного виховання в закладах вищої освіти завдяки розвитку спортивної культури студентів. Оскільки для студентського спорту притаманна низка різноманітних форм фізичної активності, його, без сумніву, можна вважати не лише способом розвитку спортивної культури, а й основним засобом реформування в галузі фізичного виховання в закладах вищої освіти, яке передусім має здійснюватися в контексті формування суб'єктності майбутнього фахівця як носія спортивної культури і здоров'я.

Перспективи подалыших наших досліджень убачаємо в застосуванні системного підходу щодо розкриття змісту сучасної спортивної підготовки, що забезпечуватиме цілеспрямований розвиток спортивної культури майбутніх фахівців фізичного виховання.

\section{СПИСОК ВИКОРИСТАНОЇ ЛІТЕРАТУРИ}

1. Білогур В. С. Концепт спорту в ракурсі теоретико-методологічних засад спортивного менеджменту - антропології, онтології та арт-терапії / В. Є. Білогур // Гуманітарний вісник ЗДІА. - 2017. Вип. 71. - С. 26-34.

2. Визитей Н. Н. Социология спорта : курс лекций / Н. Н. Визитей - К. : НУФВСУ «Олимпийская литература», 2005. - 247 с.
3. Голоцван О. А. Спорт заради розвитку : методичний посібник 3 підготовки інструкторів програми / О. А. Голоцван, Н. В. Зимівець та ін. ; за заг. ред. Н. Зимівець. - Київ : Фенікс, 2017. - 208 с.

4. Закон України «Про фізичну культуру і спорт» від 24.12.93 № 3809-XII . URL: https://zakon.rada.gov. ua/laws/show/3808-12 (дата звернення: 17.12.2020).

5. Інформаційне суспільство у світі та Україні: проблеми становлення та закономірності розвитку : колективна монографія / [М. А. Ажажа та ін. ; за ред. д-ра філос. наук, проф. В. Г. Воронкової]. - Запоріжжя : ЗДІА, 2017. - 283 с.

6. Келлер В. С. Теоретико-методичні основи підготовки спортсменів / В. С. Келлер, В. М. Платонов. Львів : УСА, 1992. - 270 с.

7. Мельник М. Г. Становлення та розвиток студентського спорту України у XXI столітті: дис. ... канд. наук із фіз. виховання та спорту : 24.00.01/ Мельник Михайло Григорович. - Львів, 2016. - 231 с.

8. Мельник М. Студентський спорт: перспективи наукових досліджень / М. Мельник, М. Пітин // Вісник Придніпров’я. - Львів, 2015. - № 3. С. 73-76.

9. Модельный закон о студенческом спорте. URL: https://zakon.rada.gov.ua/laws/show/997_a10 (дата звернення: 17.12.2020).

Дата надходження до редакиіï: 25.03.2020 p. 